\title{
Roles of Family in Introducing Early Sexual Education to Children
}

\author{
Ellya Rakhmawati ${ }^{1, *}$, Noor Rochman Hadjam², Dita Permata Aditya ${ }^{3}$, \\ Adhitya Riska Yunita ${ }^{4}$
}

\author{
${ }^{1}$ Muhammadiyah Yogyakarta University \\ 2,3,4 Gadjah Mada University \\ *Corresponding author. Email: ellya.rakhmawati.pasca17@mail.umy.ac.id
}

\begin{abstract}
Sexual education in Indonesia is remained Taboo, so many parents and schools do not have the awareness to provide sexual education to the children. However, some families tried to educate their children about sexuality. This study answers questions raised which how parents are involved in providing sexual education to early childhood. Researchers used a qualitative approach. Depth interviews have been done to the five parents. Researchers found three main themes which are relationships between parents and children; materials and media of sexual education; and parents' roles and methods in educating sexuality. Through those themes, researchers revealed the roles of family in introducing sexual education to early childhood in a comprehensive and in-depth manner. This study concludes that family is not only conveying sexual education contents, but also implementing various methods and strategies for learning, and build positive relationships to the children.
\end{abstract}

Keywords: Early Childhood, Parents, Sexual Education.

\section{INTRODUCTION}

Child sexual abuse (CSA) is a serious problem that occurs in society. The number of child sexual abuse case increases every year (Homma et al., 2016) [1]. Boys and girls under 18 years had experienced sexual abuse through an unwanted penetrating touching (Osadan \& Reid, 2015; Ji et al., 2013; Barth et al., 2013 [2,3,4]. In addition, United Nations Children's Fund showed the data on areas with the highest case of violence, which are Papua (37\%), East Nusa Tenggara (31\%), Central Java (24\%), and Aceh (13\%) (UNICEF, 2016) [5]. One of the CSA cases occurred in Jakarta International School and the perpetrator worked as the cleaning service officer in the school, made the case as a top of iceberg of CSA cases (Oktavianingsih \& Ayriza, 2018; Tirtawinata, 2016) [6,7]. Many other CSA cases happened and have not been resolved in Indonesia.

Sexual abuse is an act that is carried out intentionally (contact) or non-contact which leads to sexual activity where most victims are children because they have no power to refuse and do not give consent to the sexual violence perpetrator. Children who engage in sexual abuse can make them unprepared for their development and tend to break the law in the society (Waid-Lindberg \& Mohr, 2019; Zhang et al., 2015) [8,9]. Victims of CSA have tendency to be a perpetrator of sexual violence in the future (Osadan \& Reid, 2015; Miron \& Orcutt, 2014) $[10,11]$.

Sexual abuse can occur due to various factors, including parents that have important roles in children's engagement in sexual abuse. Other studies revealed that family is an important factor in causing children to experience sexual abuse (Laeheem, 2017) [12]. Andari et al., (2019) stated that knowledge, attitude, and parents' behavior have an impact on preventing the uplifting of CSA cases [12]. Sexual education from parents can improve sexual health, gender identity, and interpersonal relationship (Breuner \& Mattson, 2016) [13]. Therefore, family has important role in guiding children to fulfill the needs of sexuality development.

During early childhood sexuality development, the family plays fundamental role in protecting an 
d caring for children to prevent CSA. Family becomes the first learning source for children which will affects their sexual awareness and roles in gender as male or female (Ganji et al., 2017) [14]. Child sexual development mentioned by Santrock (2020) said that children aged 3 to 7 are in a phallic phase when they start to know that they have different sex, begin to show their interest and play with their own genital [15]. Children learn, think, and feel about sexuality by creating attitudes and behavior (Erhamwilda et al., 2017) [16]. Hence, children cognitively can be taught about something simple, including sexual problems.

Children should have a chance to discuss sexuality with their parents in order to not make them confused about their sexual experience which can be experienced in the neighborhood (Brouskeli \& Sapountzis, 2017) [17]. But, the understanding of sexual education often misunderstood as something bad by society in Indonesia that makes children hesitate to tell their parents about sexuality. It is because the sexual discussion is considered taboo (Oktavianingsih \& Ayriza, 2018; Pohlman, 2017; Kocsis, 2017) [6, 18, 19]. Parents prefer not to talk or feel incapable to provide appropriate answers about sexuality when their children ask (Pandia et al., 2017; Oktavianingsih \& Ayriza, 2018; Tabatabaie, 2015) [20, 6, 21].

Parents have a big role in delivering information about sexual education to the children (Martin \& Torres, 2014) [22], starting with simple thing, such as introducing gender, so that children can avoid CSA. In addition, parents also want their children to not go with a stranger alone as a part of sexual education (Rudolph et al., 2018) [23]. On the other hand, parents can explain social norms, for instance, there are provisions about things that can and cannot be touched with people who have different sexes (Rakhmawati et al., 2017) [24].

Based on other literacy studies, researchers concluded that parents have significant roles in children's understanding of sexuality. Researchers uphold the issue as an important question in this study, which is how the roles of family in giving sexual education to early age children.

\section{METHOD}

This study used qualitative method and phenomenology approach. In addition, participants in this study are classified based on certain criteria in line with Moleong's statement (2014) [25] that the research subject are selected based on the compatibility of the research context, so that the researcher can dig up the information needed. Participants criteria applied by the researchers were parents who have children aged 4-6 years and parents aged 20-50 years with different levels of understanding and knowledge about sexual education.

The data collection method is a semi-structured in-depth interview in which the interview questions have been compiled by the researcher. After collecting data, researchers triangulated the data by applying data source triangulation by using more than one participant to obtain information. The next step, researchers analyse and interpret the data. Researchers used technique by Miles and Huberwan (in Sugiyono, 2015) [26].

\section{RESULT}

\subsection{Description of Participants and The Relationships with Their Children}

First participant is IS, a mother, aged 41 years old, and works as a lecture. IS has two children categorized as early children which are NJ and NA. IS uttered that her daughters are close with her and husband. Regarding parenting patterns, IS admitted that she always observes, controls, and teaches them about the concept of risk. Besides, IS did observing forms, such as selecting their children's friends and observing their activities. IS set safe play areas for their children and limits their playtime. Not only that, IS encouraged her children not to behave deviantly.

Table 1. Participant and Participant Child's Identity

\begin{tabular}{|l|l|l|}
\hline $\begin{array}{l}\text { Participant's } \\
\text { Name }\end{array}$ & $\begin{array}{l}\text { Participant } \\
\text { Child's Name }\end{array}$ & $\begin{array}{l}\text { Participant } \\
\text { Child's Age }\end{array}$ \\
\hline IS & NJ \& NA & 5 \& 6 \\
\hline AC & JV & 5 \\
\hline UM & AH & 5 \\
\hline LL & DN & 5 \\
\hline EN & MM & 5 \\
\hline
\end{tabular}

Second participant is AC, a mother, aged 39 years old, and works as private employee. AC has two sons and one of them is an early child who is JV. $\mathrm{AC}$ feels that her son is close to her and husband. She said that mother tends to be dominant in parenting her children but she did not limit her husband to engage relationship with their children. Her husband 
still takes time to communicate with children in situations such as eating, bathing, and before going to bed. Regarding communication, AC and her husband discuss many things with their children, such as school and play activities.

The third participant is UM. UM is a mother, aged 33 years old, and works as a kindergarten teacher. UM has a son named AH. Similar to AC, $\mathrm{UM}$ feels that $\mathrm{AH}$ is close to her and husband, although she is more dominant in parenting. UM monitors AH's activities by limiting him to play gadget. In addition, UM often gives her son a message with the impression of scaring him. She implemented the message with the concept of risk such as if a child going far away, they could be kidnapped by bad people. Regarding communication, UM used activities of playtime and before bedtime.

Fourth participant is LL, a mother aged 31 years old, and works as private employee. LL has a son named DN. According to LL, DN is closer to her than her husband. She accompanies her son while her husband is busy working. Regarding parenting, LL implements democratic parenting pattern which free her son to do his activities as he desired. LL also maintains two-way communication with DN such as asking DN's activities after returning from work. LL also took initiative to ask her son condition first.

Last participant is EN, a housewife aged 30 years. EN has two daughters and one of them is an early child who is MM. EN mentioned that she monitors MM's activities, such as she only permits her daughter to play with certain friends. EN also says that MM was taught to take care herself independently in the bathroom, so her father does not need to help her. Regarding communication pattern, EN revealed that she and her daughters do two-way communication. MM takes the initiative to start the communication.

\subsection{Parents Strategy and Method in Implementing Sexual Education to Children at Early Age}

Learning media and material was given by parents in various learning strategy and methods. Five participants uttered that sexual education must be given to the children at early age. IS and UM taught sexual education to their children since they started to communicate. LL provided sexual education since her child started asking about sexuality. However, there were differences related to the appropriate age of children when parents provided sexual education. IS and AC mentioned that they provided sexual education to their children since baby or around 6 months. Meanwhile, AH had sexual understanding since he was 2 years old, DN since he was 3 years old, and MM started at the age of 4.

IS and AC had similar strategy in implementing sexual education to their children. Both participants mentioned that sexual education should be implemented consistently and adapted to the development stage of each child. IS mentioned that she answered the questions consistently so that her children. AC provided more materials related to sexual education to JV.

Last strategy, parents took an advantage in various situations to provide sexual education. Parents provided materials while children were playing or gathering together. Most participants revealed that they usually provided sexual education before bedtime. Meanwhile, IS and UM provided sexual education while bathing their children. In addition, AC also provided sexual education to JV through many other methods, one of them by inserting sexual education material through a daily conversation, especially after JV did deviant behaviour. AC mentioned that she usually delivered material related to sexual education engaged with her child's behavior which she thought was not polite, such as always kissing older people.

"But if there are people you do not know you cannot touch and kiss them. Mom and Dad who can only do that. Maybe it is just mom and dad, because you are still a child, you can only give a kiss on the cheeks, forehead, and hands." (AC, W.OT.3)

LL also used various methods in delivering sexual education to DN. LL tried to explain sexual education material slowly to DN, even though DN had not ready to bathe himself. In addition, LL did not only explain to her child, she also provided sexual education to the grandparents who also take care of her child.

During implementing sexual education, parents should learn how to implement sexual education for children. UM revealed that she had to learn deeply so that she could answer children's questions about sexuality properly even though she had parenting training from child's school. Similar to UM, AC also needs to learn about child behaviour. AC was confused about whether JV's behaviour about touching his genital is normal behaviour at his age or a form of deviant behaviour. On the other side, IS also revealed that she had difficulty answering her 
child's question about sexuality. Besides, participants felt the partner's lack of involvement. However, their children showed close relationship to father, UM and AC felt that their husband were not much engaged in providing sexual education.

Besides, the five participants also being provided by the school about how to implement sexual education to children. The training program from school helped the participants. EN said that she should say the scientific name of genital. UM, AC and IS mentioned that they usually reviewed sexual education material that has been learned by children in school while at home.

"With the additional learning in the school, so I got the benefit by strengthening that is given in school. When the materials have been provided at home, it is strengthened by repeating it at school, I will repeat again at home, children will remember... (they) remember quickly and will understand." (IS, W.OT.01)

\subsection{Discussion}

In General, in the early childhood learning process, the role of parents is more important than the roles of school or the community (Ma et al., 2015) [27], including in the context of sexual education (Martin \& Torres, 2014) [22]. Parents have a role in introducing early sexual education. Through this study known that parents applied various strategies and learning methods to implement sexual education.

The family has the responsibility to be aware and understand child sexual development without waiting for children to ask questions first (Uçar in Güder \& Alabay, 2018) [28]. In this study parents had time differences in starting sexual education. The age difference in providing sexual education for children varies widely (Sullivan \& Caterino, 2008) because of the different perspectives between each parent. Participants who provided sexual education when their children were toddlers realized that they have to implement it as early as possible [29]. As stated by Berk (2013), children can absorb and process information quickly [30].

Communication between parents and children is an important part for conveying sexual education (Walsh \& Brandon, 2011) [31]. In line with this study, communication between participants and their children is two-way communication which parents and children had an open discussion. Besides communication, parents can monitor children to prevent CSA (Walsh \& Brandon, 2011) [31]. This study also stated that participants monitor children's activity and select their friends to protect from CSA.

Another form of parental involvement was teaching children after they did deviate behavior. Those findings are in line with Babatsikos and Miles (2015) which found that parents should detect a child's behavior and find the solution for their deviant act [32]. This method encourages children to understand their deviate behavior and realize to not do it again in the future (Mendelson et al., 2015) [33].

Parents need to obtain more information about children's sexual development in order to acquire sufficient skills and knowledge in sexual education practice (Nghipondoka-Lukolo \& Charles, 2016) [34]. Guo et al. (2019) mentioned that only parents who had proper knowledge are able to provide sexual education to their children [35]. In this study, parents had received parenting training can understand related to content, media, and strategy used to implement sexual education for early childhood. A participant EN revealed that she started to teach the scientific name of genital after receiving sexual education program from the school. EN findings supported the study that parents need to teach their children about the scientific name of genitals without disguising them (Güder \& Alabay, 2018) [28]. Not only that, Guo et al. (2019) stated that the more family member understand CSA prevention program will strengthen children's social support [35]. This supported the findings of LL who provides understanding about sexual education to the grandparents.

All participants tried to answer every child's question related to sexuality to avoid children to look for other accurate sources such as friends or the internet (Nugraha et al., 2012) [36]. However, parents are still confused about finding the right way to answer children's questions (Morawska et al., 2015) [37], similar to this study's findings which found that participant UM had difficulty in explaining pregnancy and childbirth. Maternal pregnancy and childbirth are among the topics frequently asked by children (Frankham, 2006) [38]. Each parent has their answer. EN and LL explained that pregnancy was given by God. According to Guder and Alabay (2018), mothers tend to answer based on religious beliefs (for example, children are a grace from God) rather than explaining it scientifically because they do not feel capable to explain it scientifically and to make children stop questioning it. 
All participants who are mothers told that children's father has a lack of involvement in sexual education. This finding supports previous studies which stated that mother is more involved in child sexual education (Guo et al., 2019; Chen et al., 2007) $[35,39]$, without having to look up to child's gender (Walsh et al., 2012) [40]. Guo et al. (2019) mentioned that the father actually wants to have critical thoughts, but they frequently think that child education is the responsibility of their mother [35]. On the other side, Pandia et al. (2017) stated that the mother is more dominating in parenting while children at an early age and father dominate in the final phase as children, especially in the puberty phase of a son [20].

The cooperation between parents and schools are also needed. The school and families have to share joint responsibility in providing related to sexual health and psychological well-being of children (Pop \& Rusu, 2015) [41]. All the participant's children had sexual education provided by the school, then parents strengthen and reviewed at home. This finding is in line with the previous study which mentioned that the parents' involvement in CSA prevention program could stimulate parents and children to discuss sexual education contents together (Kenny, 2010) [42].

\subsection{Conclusion}

This research explained the roles of parents in providing early childhood sexual education comprehensively. The role of parents in conveying sexual education is not only limited in its contents, but also the use of media, proper situation, and learning method. Not only that, the relationship between children and parents become the important components in providing sexual education to children. However, this study has limitations that is the five participants are mothers. So, there is no findings from the father that enrich the result of this study. The reason why the fathers are not the participants in this research because the fathers tend to focus in their work and less involvement in children parenting.

\section{AUTHORS' CONTRIBUTIONS}

This study can be used as references for further research which related to the research fields of developmental psychology, child psychology, and sexual education.

\section{ACKNOWLEDGMENT}

The researchers are grateful for the participants involved in this study, which are parents of the early childhood and the other parties involved in this research from the preparation to the publication stage.

\section{REFERENCES}

[1] Y. Homma, N. Wang, E. Saewyc, \& N. Kishor. The Relationship between Sexual Abuse and Risky Sexual Behavior among Adolescent Boys: A Meta-Analysis. J Adolesc Health, 51(1), (2016), 18-24. DOI: 10.1016/j.jadohealth.2011.12.032.

[2] R. Osadan, \& E. Reid. The Importance of Knowing Child Sexual Abuse Symptoms in the Elementary Teacher's Work. International Journal of Humanities and Social Science, 5(7), (2015), 20-32. DOI: 10.1016/S01452134(00)00212-X.

[3] K. Ji, D. Finkelhor, \& M. Dunne. Child Abuse \& Neglect Child Sexual Abuse in China: A Meta-Analysis of 27 Studies. Child Abuse \& Neglect, 37(9), (2013), 613-622. DOI: 10.1016/j.chiabu.2013.03.008.

[4] J. Barth, L. Bermetz, E. Heim, S. Trelle, \& T. Tonia. The Current Prevalence of Child Sexual Abuse Worldwide: A Systematic Review and Meta-Analysis. Int J Public Health (2013), 58(3), (2013), 469-483. DOI: 10.1007/s00038012-0426-1.

[5] United Nations Children's Fund (UNICEF). Indonesia as A Pathfinder to End Violence against Children (No. 1-25). (2016). Accessed on 01 Juni 2020 from www.aidsdatahub.org.

[6] E. Oktavianingsih \& Y. Ayriza. Teachers' Knowledge and Belief for Educating Sexuality In Kindergarten Children. International Journal of Pedagogy and Teacher Education (IJPTE), 02(2), (2018), 307-318. DOI: 10.20961/ijpte.v2i2.19760.

[7] C. M. Tirtawinata. Importance of Sex Education Since Early Age for Preventing Sexual Harassment. Humaniora, 7(2), (2016), 201-209. DOI: 10.21512/humaniora.7i2.3523.

[8] C. A. Waid-Lindberg, \& N. L. Mohr. Child Sexual Abuse. The Encyclopedia of Women 
and Crime, (2019), 1-7. DOI: 10.1002/9781118929803.ewac0051.

[9] W. Zhang, J. Chen, \& F. Liu. Preventing Child Sexual Abuse Early: Preschool Teachers' Knowledge, Attitudes, and Their Training Education in China. Sage Journals, 5(1), (2015), 1-8. DOI: 10.1177/2158244015571.

[10] R. Osadan, \& E. Reid. The Importance of Knowing Child Sexual Abuse Symptoms in the Elementary Teacher's Work. International Journal of Humanities and Social Science, 5(7), (2015), 20-32. DOI: 10.1016/S01452134(00)00212-X.

[11] L. R. Miron, \& H. K. Orcutt. Pathways from Childhood Abuse to Prospective Revictimization: Depression, Sex to Reduce Negative Affect, and Forecasted Sexual Behavior. Child Abuse \& Neglect, 38(11), (2014), 1848-1859. DOI: 10.1016/j.chiabu.2014.10.004.

[12] K. Laeheem. Family and Upbringing Background of Students with Bullying Behavior in Islamic Private Schools, Pattani Province, Southern Thailand. Asian Social Science, 9(7), (2017), 162-172. DOI: 10.5539/ass.9n7p162.

[12] D. I. Andari, O. Woro, \& A. Yuniastuti. The Effect of Knowledge, Attitude, and Parents Behavior towards Sex Education Parents with Sexual Violence Incident. Public Health Perspective Journal, 4(9), (2019), 141-148.

[13] C. C. Breuner, G. Mattson, \& Committee on Psychosocial Aspects of Child and Family Health. Sexuality education for children and adolescents. Pediatrics, 138(2), (2016), e20161348.

[14] J. Ganji, M. H. Emamian, R. Maasoumi, A. Keramat, \& E. M. Khoei. Sexual Health Education at Home: Attitude and Practice of Iranian Parents. Iran J Public Health, 47(1), (2018), 146-147. Accessed on June $4^{\text {th }} 2020$ from www.pubmed.ncbi.nlm.nih.gov.

[15] J. W. Santrock. A Topical Apporach to LifeSpan Development (10 ${ }^{\text {th }}$ ed.). (2020). New York: McGraw-Hill Education.

[16] Erhamwilda, A. D. Suhardini, \& N. Afrianti. Analysis of Early Childhood Teacher Perceptions of Sex Education in an Islamic
Perspective. Mimbar, 33(1), (2017), 81-89. DOI: 10.29313/mimbar.33i1.2071

[17] V. Brouskeli, \& A. Sapountzis. Early Childhood Sexuality Education: Future Educators' Attitudes and Considerations. Research in Education, 99(1), (2017), 56-68. DOI: $10.1177 / 0034523717740149$.

[18] A. Pohlman. Sexual Violence as Torture: Crimes against Humanity during the 1965-66 Killings in Indonesia. Journal of Genocide Research, 19(4), (2017), 574-593. DOI: 10.1080/14623528.2017.1393949.

[19] T. Kocsis. A Critical Analysis of Sexuality Education in the United States: Toward an Inclusive Curriculum for Social Justice. (2019), Routledge.

[20] W. S. S. Pandia, Y. Widyawati, \& E. Indriati. Sexual Education Knowledge for Early Childhood. Advances in Social Science, Education and Humanities Research (ASSEHR). 3rd International Conference on Early Childhood Education (ICECE-16), 58, (2017), 446-450. DOI: 10.2991/icece16.2017.78.

[21] A. Tabatabaie. Constructing the Ideal Muslim Sexual Subject: Problematics of School-Based Sex Education in Iran. Sex Education: Sexuality, Society, and Learning, 15(2), $\left(2015^{\text {b }}\right)$ 37-41. DOI: 10.1080/14681811.2014.992066

[22] K. A. Martin \& J. M. C. Torres. Where did I Come From? US Parents' and Preschool Children's Participation in Sexual Socialisation. Sex Education: Sexuality, Society and Learning, 14(2), (2014), 174-190. DOI: $10.1080 / 14681811.2013 .856291$.

[23] J. Rudolph \& M. J. Zimmer-Gembeck. Parents as protectors: A qualitative study of parents' views on child sexual abuse prevention. Child Abuse \& Neglect, 85, (2018), 28-38. DOI: 10.1016/j.chiabu.2018.08.016

[24] E. Rakhmawati, T. Suyati, I. Khasanah, \& N. Kusumaningtyas. Penerapan Pendidikan Keluarga sebagai Prevensi Kekerasan Seksual pada Anak. Semarang: Universitas PGRI Semarang. Hasil Penelitian Hibah APBU Universitas PGRI Semarang. Hlmn. 3. PAUDIA: Jurnal Penelitian Dalam Bidang 
Pendidikan Anak Usia Dini. Vol. 7, No. 1. (2017).

[25] L. J. Moleong. Metodologi Penelitian Kualitatif. (2014). Bandung: Remaja Rosdakarya.

[26] Sugiyono. Metode Penelitian Bisnis (Pendekatan Kuantitatif, Kualitatif, dan $R$ \& D). (2015). Bandung: Alfabeta.

[27] X. Ma, J. Shen, H. Y. Krenn, S. Hu \& J. Yuan. A meta-analysis of the relationship between learning outcomes and parental involvement during early childhood education and early elementary education. Educational Psychology Review, 28(4), (2016), 771-801. DOI: $10.1007 / \mathrm{s} 10648-015-9351-1$

[28] S. Y. Güder \& E. Alabay. Children's Questions and Answers of Parents: Sexual Education Dilemma. International Journal of Progressive Education, 14(6), (2018), 138-151. DOI: 10.29329/ijpe.2018.179.11.

[29] A. Sullivan \& L. C. Caterino. Addressing the sexuality and sex education of individuals with autism spectrum disorders. Education and Treatment of Children, (2008), 381-394. DOI: 10.1353/etc.0.0001.

[30] L. E. Berk. Child development (9th ed). (2013), Singapore: Pearson

[31] K. Walsh, \& L. Brandon. Their Children's First Educators: Parents' Views about Child Sexual Abuse Prevention Education. J Child Fam Stud, 21(5), (2011), 734-746. DOI: $10.1007 / \mathrm{s} 10826-011-9526-4$

[32] G. Babatsikos, \& D. Miles. How parents manage the risk of child sexual abuse: a grounded theory. Journal of child sexual abuse, 24(1), (2015), 55-76. DOI: $10.1080 / 10538712.2015 .981352$

[33] T. Mendelson, \& E. J. Letourneau. Parentfocused prevention of child sexual abuse. Prevention Science, 16(6), (2015), 844852. DOI: $10.1007 / \mathrm{s} 11121-015-0553-\mathrm{Z}$

[34] L. N. Nghipondoka-Lukolo \& K. L. Charles. Parents' Participation in the Sexuality Education of Their Children in Namibia: A Framework and an Educational Programme for Enhanced Action. Global Journal of Health Science, 8(4), (2016), 172-187. DOI: 10.5539/gjhs.8n4p172.
[35] S. Guo, J. Chen, B. Yu, Y. Jiang, Y. Song, \& Y. Jin. Knowledge, Attitude and Practice of Child Sexual Abuse Prevention among Parents of Children with Hearing Loss: A Pilot Study in Beijing and Hebei Province, China. Journal of Child Sexual Abuse, 28(7), (2019), 781-798. DOI: 10.1080/10538712.2019.1627688.

[36] P. Nugraha, K. Cahyo, \& T. A. Kusumaningrum. Perilaku Ibu terhadap Pemberian Pemahaman Kesehatan Reproduksi pada Anak Putra Tunagrahita. Seminar Nasional World Fit for Children. (2012). Semarang: Diponegoro University.

[37] A. Morawska, A. Walsh, \& M. Grabski. Parental Confidence and Preferences for Communicating with their Child about Sexuality. Sex Education: Sexuality, Society and Learning, 15(3), (2015), 235-248. DOI: 10.1080/14681811.2014.996213.

[38] J. Frankham. Sexual Antimonies and Parent/Child Sex Education: Learning from Foreclosure. Sexualities, 9(2), (2006), 236254. DOI: $10.1177 / 1363460706063120$

[39] J. Chen, M. P. Dunne, \& P. Han. Prevention of Child Sexual Abuse in China: Knowledge, Attitudes, and Communication Practices of Parents of Elementary School Children. Child Abuse \& Neglect, 31(7), (2007), 747-755. DOI: 10.1016/j.chiabu.2006.12.013.

[40] K. Walsh, L. Brandon, \& L. Chirio. MotherChild Communication about Sexual Abuse Prevention. Journal of Child Sexual Abuse, 21(4), (2012), 399-421. DOI: 10.1080/10538712.2012.675424.

[41] M. V. Pop \& A. S. Rusu. The Role of Parents in Shaping and Improving the Sexual Health of Children-Lines of Developing Parental Sexuality Education Programmes. ProcediaSocial and Behavioral Sciences, 209(July), (2015), 395-401. DOI: 10.1016/j.sbspro.2015.11.210.

[42] M. C. Kenny, \& S. K. Wurtele. Child Abuse \& Neglect Children's Abilities to recognize a "Good" Person as a Potential Perpetrator of Childhood Sexual Abuse. Child Abuse \& Neglect, 34(7), (2010), 490-495. DOI: 10.1016/j.chiabu.2009.11.007. 